\title{
An Evaluation of the Performance through the Comparison of Kinematic Variables for the Official Records in World Women's Triple Jumper
}

\author{
Jae-Kyun Ryu* \& Geon-Tak Kim \\ Kyung Hee University
}

[Purpose] The purpose of this study was to examine the difference and consistency of kinematic variables for each athlete by selecting the official records of the world's elite female triple jumpers to evaluate the performance level. [Methods] Three athletes who won the prizes at the World Championships Daegu 2011 Women's Triple Jump were selected as the study subjects, and only the successful trials were used for analysis. Pearson's correlation analysis was conducted with the kinematic variables in the hop, step, and jump phase, respectively. Also, kinematic variables with statistically significant correlations between braking time and pushing time and related variables were described separately. The duty factor and support factor for the hop, step, and jump of support phases were calculated. [Results] The successful trials rate were $66.7 \%$ for Olha, $50 \%$ for Olga, and $83.3 \%$ for Caterine. In the last three stride distances of the approach run, Olha and Caterine had a "medium-long-short" pattern and Olga had a "long-short-medium" pattern. There was no difference in the duty factor value between hop and jump phases in the 'hop-dominate' technique type, but there was a difference in the jump phase in the 'balance' technique type, and the duty factor value in the step of both technique types was greater than that of hop and jump phases. As for the percentage of the support factor, Olha and Caterine had a characteristic that the percentage of braking time in step and jump phases was opposite. On the other hand, Olga had the same percentage for the hop and step phase, and a smaller percentage for the jump phase. [Conclusion] To increase the accuracy of the board touch-down, maintain a certain last stride(1SL) depending on the technique type. This consistency of the approach run increases reduces distance loss on the take-off board and increases the successful rate of each trial. The duty factor can judge both the performance level and the technique type of triple jump, and the support factor is a variable that can classify the technique types of hop, step, and jump phases. If both the relative time required for the triple jump and the variability of the support time(braking and pushing) for each phase are constant, the difference in records by trial will be small.

Key words: Women’s triple jump, Braking, Pushing, Consistency, Variability, Performance

\section{서 론}

논문 투고일 : 2020. 12. 01.

논문 수정일 : 2021. 01. 25.

게재 확정일 : 2021. 03. 04.

* 교신저자 : 류재균(ryu69kor@khu.ac.kr).
세단뛰기는 선수가 지면에 세 번의 접촉(홉, 스텝, 점프) 을 하는 동안에 신체 무게중심의 수직속도를 발생시킴과 동 시에 수평속도의 손실을 최소화하는 육상경기 도약 종목이 
다. 세단뛰기 연구들은 속도의 손실 관계, 최적의 국면비 (Yu \& Andrews, 1998), 기술 유형에 따른 국면비의 비율 (Yu \& Hay 1996; Yu, 1999), 속도 전환계수를 통한 각 국 면비의 시뮬레이션(Hay, 1992; Allen et. al., 2010) 그리 고 팔 동작에 따른 기술 유형의 분류 등 경기력과 관련된 연 구들이 수행되었고 현재에도 다양한 경기력 수준의 선수들 을 대상으로 연구를 계속해서 진행하고 있다.

과거 10 여 년 동안 세단뛰기 연구들은 엘리트 선수들의 경기력 향상에 큰 공헌을 하였고 주요 연구대상들은 세계 정 상 수준에 있는 선수들의 운동학적·운동 역학적 변인들을 산출하여 서로 비교하고 세계 정상의 엘리트 선수가 되기 위 한 변인들의 기준치를 제시하였다. 그리고 이러한 측정치를 기준으로 최적의 국면비의 분배와 기술 유형을 홉 강조형 (hop-dominate), 점프 강조형(jump-dominate) 그리고 밸런스형(balance)으로 새롭게 정립하였다(Hay, 1992). 이러한 결과는 가장 기록이 좋은 시기 하나를 선정하여 분석 함과 동시에 경기력의 차이별로 제시하여 세계 정상의 엘리 트 선수가 되기 위해 노력하는 선수들에게 기술 유형의 변화 에 대한 지표를 제공하는 데는 유용한 자료가 되었다. 하지 만 선수들의 경기력이 좋은 하나의 시기만을 분석하여 경기 력 향상에 초점을 맞추는 것보다는 성공적으로 수행한 여섯 번의 시기를 모두 분석한다면 선수들 개개인의 경기력 향상 을 위한 조금 더 구체적인 분석을 할 수 있을 것이다. 더욱 구체적인 선수들의 경기력을 평가하기 위해서는 최고기록 운동수행뿐만 아니라 나머지 차기 기록 운동수행의 시기들 도 분석하여 비교한다면 선수들의 결점을 보완하고 경기력 예측에 도움을 줄 수 있을 것이라는 연구의 필요성이 최근에 대두되고 있다. 더불어 선수들의 경기력 수준 평가에 있어 서 여섯 번의 시기의 성공 확률과 성공한 시기의 기록의 평 균을 통해 다음 경기의 시기 성공률과 경기력을 예측할 수 있을 것이다. 더 나아가 종적으로 추적분석을 하면 보다 명 확한 선수의 경기력 수준을 평가할 수 있다.

선수가 우수한 경기력을 갖추기 위해서는 운동수행의 가 변성이 작고 일관성이 높아야 하며, 숙련된 퍼포먼스가 발 현되기 위해서는 수많은 반복 수행을 통한 최적의 운동 패턴 재현이 필수적이다(Maraj et. al., 1993). 세단뛰기선수들 이 동작을 수행하는 데 있어서 운동학적 변인의 가변성이 커 질수록 운동수행의 정확성은 감소하기 때문에 경기력 수준 향상의 목표를 달성하기 위해서는 국면별 움직임의 운동학 적 변인의 가변성을 조사할 필요가 있다. 따라서, 이러한 국
면별 동작 수행에 있어 운동학적 변인 간 가변성과 관련된 연구를 통해 선수들의 경기력 평가를 객관적으로 할 수 있는 기초적인 토대가 만들어져야 할 것이다.

세단뛰기는 도움닫기로부터 수평속도를 얻고 점차 가속 하여 세 번의 접지와 이륙 국면을 수행하면서 모래사장까지 최소한의 수평속도 손실로 세 국면을 수행하여야 좋은 경기 력을 획득할 수 있다. 그러므로 각 국면에서의 도약하는 기 술 동작이 수평속도의 손실을 최소화할 수 있다. 국면별 도 약 순간의 동작 수행 타이밍은 상체를 중심으로 사지가 움직 이기 때문에 선수들이 각 국면을 수행할 때의 상체 자세와 속도 및 거리의 변화를 시기별로 조사하는 것이 선수 개개인 의 경기력 수준에 대한 일관성과 가변성을 평가하는 기본 운 동학적 변인이 될 것이다. 본 연구의 목적은 경기력 수준을 평가하기 위하여 우수한 세계 엘리트 여자 세단뛰기선수들 의 유효시기를 선정하여 선수별 운동학적 변인들의 차이와 일관성을 조사하는 것이다.

\section{연구 방법}

\section{연구대상}

본 연구의 대상자는 2011년 대구세계육상선수권대회 여자 세단뛰기 결승에 진출하여 입상한 선수 3 명을 연구대 상으로 선정하였으며, 선수들의 신장, 체중 그리고 나이는 각각 $180 \mathrm{~cm} \pm 3.51,63 \mathrm{~kg} \pm 6.11,27 \mathrm{yrs} \pm 1.00$ 이 다. 연구대상자들의 세단뛰기 경기력 정보는 〈Table 1)과 같다.

\section{실험 방법}

총 6대의 비디오카메라 설치는 관중석과 도움닫기 주로 에 평행하게 배치하여 선수들의 모든 동작을 촬영하였다. 6 대의 Sony 비디오카메라(PD170)는 프레임 속도는 60 frames/sec, 노출시간은 $1 / 500 \mathrm{sec}$ 로 설정하였다. 통제점 틀은 $1 \mathrm{~m} \times 1 \mathrm{~m} \times 2 \mathrm{~m}$ 로 조립하여 총 $25 \mathrm{~m}$ 분석구간의 3 차원 좌표를 설정하기 위하여 촬영하였다. 전역 좌표계의 정의는 $\mathrm{Y}$ 축을 운동 진행(전후) 방향, $\mathrm{X}$ 축은 좌우 방향으로 정의하였으며, Z축은 XY평면에 대해 직교하는 수직 방향으 로 정의하였다. 
자료처리 및 분석은 Kwon3D ver. 3.1 소프트웨어 (Visol, KOR)를 이용하였고, 샘플링 주파수는 $60 \mathrm{~Hz}$ 로 설 정하였다. 인체 모델링은 19 개 신체 관절 중심점에 의한 14 개의 분절로 연결된 강체 시스템으로 정의하였다. 3 차원 좌 표값 산출은 DLT 방법(Abdel-aziz \& Karara, 1971)을 사 용하였으며 재구성 오차는 $1.04 \mathrm{~cm}$ 이다. 좌표값은 버터워
스 4차 저역 통과 필터를 사용하여 잡음을 평활화하였으며 차단 주파수는 $7.4 \mathrm{~Hz}$ 로 설정하였다. 인체분절지수는 Plagenhoef(1983)의 자료를 이용하였다. 동조는 perform software genlock 기능을 이용하여 도움닫기 4개의 스텝 (3개의 스트라이드)과 구름판(홉), 스텝, 점프의 이륙 순간 으로 설정하였다(Fig. 1).

Table 1. Performance of the subjects

\begin{tabular}{|c|c|c|c|c|c|c|}
\hline Subjects & $\begin{array}{l}\text { Brth. } \\
\text { (yrs) }\end{array}$ & $\begin{array}{c}\text { Personal record } \\
\text { performance } \\
\text { (m) }\end{array}$ & $\begin{array}{c}\text { Season best } \\
\text { performance } \\
(\mathrm{m})\end{array}$ & $\begin{array}{c}\text { Official } \\
\text { distance } \\
(\mathrm{m})\end{array}$ & $\begin{array}{l}\text { Actual } \\
\text { distance } \\
(\mathrm{m})\end{array}$ & $\begin{array}{l}\text { Phase } \\
\text { ratio } \\
(\%) \\
\end{array}$ \\
\hline \multirow{5}{*}{ Olha } & \multirow{5}{*}{1983} & \multirow{4}{*}{14.98} & \multirow{4}{*}{14.98} & 14.94 & 15.13 & $38: 28: 34$ \\
\hline & & & & 14.68 & 14.95 & $38: 27: 35$ \\
\hline & & & & 14.65 & 14.87 & 38:28:34 \\
\hline & & & & 14.48 & 14.72 & 38:27:35 \\
\hline & & $\mathrm{Me}$ & & $14.69 \pm 0.19$ & $14.92 \pm 0.17$ & 38:28:35 \\
\hline \multirow{4}{*}{ Olga } & \multirow{4}{*}{1984} & \multirow{3}{*}{15.25} & \multirow{3}{*}{14.96} & 14.72 & 15.07 & $35: 28: 36$ \\
\hline & & & & 14.89 & 15.13 & $36: 28: 36$ \\
\hline & & & & 14.54 & 14.83 & $37: 26: 37$ \\
\hline & & \multicolumn{2}{|c|}{ Mean \pm SD } & $14.72 \pm 0.18$ & $15.01 \pm 0.16$ & $36: 27: 36$ \\
\hline \multirow{6}{*}{ Caterine } & \multirow{6}{*}{1984} & \multirow{5}{*}{14.99} & \multirow{5}{*}{14.99} & 14.64 & 14.91 & $39: 27: 34$ \\
\hline & & & & 14.67 & 14.85 & 38:30:33 \\
\hline & & & & 14.81 & 15.10 & $38: 28: 34$ \\
\hline & & & & 14.84 & 14.97 & $36: 29: 35$ \\
\hline & & & & 14.80 & 15.10 & 38:27:34 \\
\hline & & \multicolumn{2}{|c|}{ Mean \pm SD } & $14.75 \pm 0.09$ & $14.99 \pm 0.11$ & $38: 28: 34$ \\
\hline
\end{tabular}

Phase Ratio = Phase ratio for actual distance

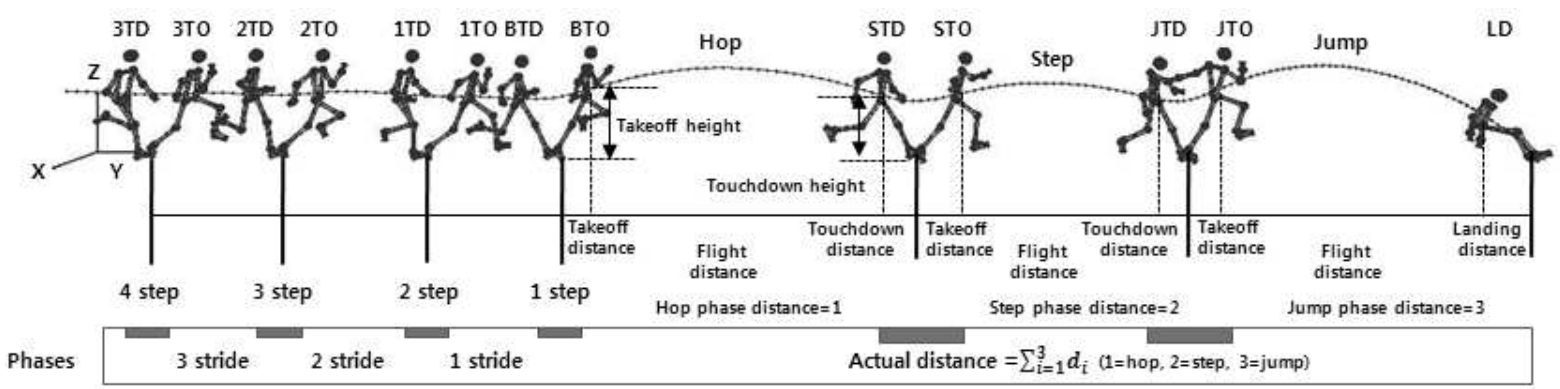

Fig. 1. The last three strides of the approach run, take-off and touch-own distance, landing distance, flight distance, each phase distance, take-off and touch-down height and actual distance(Ryu \& Chang, 2015) 


\section{자료 분석}

도움닫기 마지막 세(three) 스트라이드에서 발이 지면에 닿는 순간과 떨어지는 순간의 이벤트는 접지(touchdown)와 이륙(take-off)으로 정의하였다. 홉 국면 거리는 공식기록과 측정 거리 사이의 차이로 산출하였으며, 도움닫 기 마지막 세 스트라이드에 대한 운동학적 변인들은 스트라 이드 거리와 속도 변인만을 사용하였다. 성공 시기율 (successful trials rate)은 성공 시기 수를 총 시기 수로 나 누어 백분율로 산출하였으며, 총 6번의 시기 중 성공의 확률 을 나타내었다(식1).

$$
\text { 성공 시기율 }(\%)=\frac{\text { 성공시기수 }}{\text { 총시기수 }} \times 100
$$

홉, 스텝, 점프 지지 국면에 대한 제동시간(braking time)과 추진시간(pushing time)의 구분은 스윙 다리가 지지 다리의 무릎을 지나는 순간을 기준으로 산출하였으며, 신체 무게중심의 높이는 신장 대비 높이로 표준화하여 제시 하였다. Duty factor는 발의 지지 시간에 대한 스트라이드 국면 소요시간의 상대적인 수치로(Alexander, 2002), 각 스트라이드 국면에서 지면을 지지하고 있는 발이 정상적인 보행 동작을 수행하고 있는지를 평가하는 지표로 사용된다 (Fihl \& Moeslund, 2010). 이에 본 연구에서는 선행연구 에서 제시한 duty factor를 응용하여 각 국면 발구름 발의 지지 시간(support time 1, 2, 3: 1=hop, 2=step, 3=jump)을 홉, 스텝, 점프 국면별 소요시간(phase period 1, 2, 3: 1=hop, 2=step, 3=jump)으로 나누어 각각 산출 하였다(식2). 지지요인(support factor)은 제동시간과 추 진시간의 비율을 백분율로 나타내었다.

$$
\begin{array}{r}
\text { Duty factor } \\
=\frac{\text { Support time }}{1,2,3}_{\text {Phase period }}^{1,2,3} \\
(1=\text { hop, } 2=\text { step, } 3=\text { jump })
\end{array}
$$

통계처리는 SPSS ver. 25.0(SPSS Inc., Chicago, IL, USA) 소프트웨어를 사용하여 모든 운동학적 변인의 평균과 표준편차를 산출하고 유효한 기록 시기의 홉, 스텝, 점프 국 면별 운동학적 변인 간의 상호관계를 조사하기 위하여 Pearson's 적률상관분석을 하였다. 그리고 제동시간 (braking time)과 추진시간(pushing time)에 통계적으로 유의한 상관관계가 있는 운동학적 변인들을 구분하여 제시 하였다.

\section{연구결과}

\section{1. 도움닫기 및 국면비와 성공 시기율}

Table 2. The last three stride length for approach-run

(Unit : m)

\begin{tabular}{ccccc}
\hline \hline & & Olha & Olga & Caterine \\
\hline & 3SL & $\begin{array}{c}2.08 \\
(0.08)\end{array}$ & $\begin{array}{c}2.66 \\
(0.02)\end{array}$ & $\begin{array}{c}2.13 \\
(0.10)\end{array}$ \\
& & & & \\
Stride & 2SL & $\begin{array}{c}2.47 \\
(0.02)\end{array}$ & $\begin{array}{c}2.39 \\
(0.09)\end{array}$ & $\begin{array}{c}2.52 \\
(0.03)\end{array}$ \\
& length & & & \\
& 1.87 & 2.47 & 1.88 \\
$(0.12)$ & $(0.11)$ & $(0.18)$ \\
\hline $\begin{array}{c}\text { Phase } \\
\text { ratio } \\
(\%)\end{array}$ & $38: 28: 35$ & $36: 27: 36$ & $38: 28: 34$ \\
\hline $\begin{array}{c}\text { Successful } \\
\text { trials rate } \\
(\%)\end{array}$ & 66.7 & 50.0 & 83.3 \\
\hline \hline
\end{tabular}

( ) = Standard deviation; 3SL = Third stride length;

2SL = Second stride length; 1SL = Last stride length

〈Table 2〉는 도움닫기 마지막 세 스트라이드 거리 변인, 국면비 및 성공 시기율을 제시한 것이다. 세 선수의 국면비 를 보면 Olha와 Caterine 선수는 각각 38:28:35, 38:28:34로 홉 강조형 기술을 사용하고 있으며 Olga 선수 만이 밸런스형 기술을 사용하고 있었다. 다만 Caterine 선 수는 밸런스형 기술을 병행하는 것으로 나타났다. 그리고 세 선수의 성공 시기율은 Caterine, Olha, Olga 선수 순으 로 각각 $83.3 \%, 66.7 \%, 50.0 \%$ 로 나타났다.

구름판에서 이륙하기 전 도움닫기 마지막 세 스트라이드 거리는 Olha와 Caterine 선수가 '보통-길게-짧게' 하는 패 
턴이 나타났으며, Olga 선수는 '길게-짧게-보통'으로 하는 패턴이 나타났다. 세 선수 모두 마지막 스트라이드(1SL) 거 리의 편차가 각각 $\pm 0.12 \mathrm{~m}, \pm 0.11 \mathrm{~m}, \pm 0.18 \mathrm{~m}$ 로 가장 크게 나타났다.

Table 3. The actual phase distance for hop, step and jump phases

(Unit : m)

\begin{tabular}{ccccc}
\hline \hline & & Olha & Olga & Caterine \\
\hline & $\begin{array}{c}\text { Take-off board } \\
\text { distance loss }\end{array}$ & $\begin{array}{c}-0.23 \\
(0.03)\end{array}$ & $\begin{array}{c}-0.29 \\
(0.06)\end{array}$ & $\begin{array}{c}-0.23 \\
(0.08)\end{array}$ \\
& & & & \\
& & 5.67 & 5.42 & 5.65 \\
$\begin{array}{c}\text { Actual } \\
\text { phase } \\
\text { distance }\end{array}$ & Hop & $(0.08)$ & $(0.13)$ & $(0.08)$ \\
& & & & \\
& Step & $(0.11)$ & $(0.22)$ & $(0.18)$ \\
& & & & \\
& Jump & 5.12 & 5.47 & 5.10 \\
& & $(0.03)$ & $(0.04)$ & $(0.13)$ \\
\hline \hline
\end{tabular}

( ) = Standard deviation

구름판에서의 손실 거리와 홉, 스텝, 점프 국면의 실제 거 리 변인은 〈Table 3〉과 같다. 총 6번의 시기 중 성공 유효율 이 높을수록 구름판에서의 손실 거리가 $23 \mathrm{~cm}$ 로 작게 나타 났다. 그리고 선수들이 선호하는 기술 유형에 따라 홉 강조 형인 Olha와 Caterine 선수는 홉 국면 거리의 편차도 낮게 나타났다. 그러나 Olga 선수는 밸런스형으로 홉과 스텝에 서의 국면 거리 편차가 높게 나타났다. 특히 Caterine 선수 의 경우 스텝과 점프에서 국면 거리의 편차가 각각 \pm 0.18 $\mathrm{m}, \pm 0.13 \mathrm{~m}$ 로 높게 나타난 것은 두 가지 기술 유형을 혼합 해서 나타난 것이다.

마지막 스트라이드, 홉, 스텝, 점프 이륙 순간의 신체 무 게중심 속도 변인은 〈Table 4〉와 같다. 도움닫기 마지막 스 트라이드 이륙시 수평속도는 Caterine 선수가 $9.70 \mathrm{~m} / \mathrm{s}$ 로 가장 높았으며, Olga 선수가 $9.18 \mathrm{~m} / \mathrm{s}$ 로 가장 낮게 나타났 다. 국면별 이륙시 수평속도는 Olha 선수가 홉, 스텝, 점프 에서 각각 $7.92 \mathrm{~m} / \mathrm{s}, 7.40 \mathrm{~m} / \mathrm{s}, 6.28 \mathrm{~m} / \mathrm{s}$ 로 다른 선수들 에 비해 상대적으로 가장 낮으며, 시기별 편차 또한 가장 크 게 나타나 일관성이 떨어지는 것으로 나타났다.

홉 이륙시 수평속도 변화율은 Olga 선수가 수평속도 손실 이 $-0.37 \mathrm{~m} / \mathrm{s}$ 로 가장 적었으며, 홉 이륙시 수평속도 손실이
Table 4. Kinematic variables of CM velocity at take-off for last stride, hop, step and jump phases

(Unit : m/s)

\begin{tabular}{|c|c|c|c|c|}
\hline & & Olha & Olga & Caterine \\
\hline \multirow{4}{*}{$\begin{array}{c}\text { Horizontal } \\
\text { velocity }\end{array}$} & LS & $\begin{array}{c}9.25 \\
(0.28)\end{array}$ & $\begin{array}{c}9.18 \\
(0.09)\end{array}$ & $\begin{array}{c}9.70 \\
(0.22)\end{array}$ \\
\hline & Нор & $\begin{array}{c}7.92 \\
(0.15)\end{array}$ & $\begin{array}{c}8.81 \\
(0.11)\end{array}$ & $\begin{array}{c}8.28 \\
(0.15)\end{array}$ \\
\hline & Step & $\begin{array}{c}7.40 \\
(0.13)\end{array}$ & $\begin{array}{c}8.04 \\
(0.08)\end{array}$ & $\begin{array}{c}7.76 \\
(0.11)\end{array}$ \\
\hline & Jump & $\begin{array}{c}6.28 \\
(0.21)\end{array}$ & $\begin{array}{c}6.68 \\
(0.08)\end{array}$ & $\begin{array}{c}6.55 \\
(0.19)\end{array}$ \\
\hline \multirow{3}{*}{$\begin{array}{c}\text { Change in } \\
\text { horizontal } \\
\text { velocity }\end{array}$} & Hop & $\begin{array}{l}-1.34 \\
(0.20)\end{array}$ & $\begin{array}{l}-0.37 \\
(0.09)\end{array}$ & $\begin{array}{l}-1.42 \\
(0.28)\end{array}$ \\
\hline & Step & $\begin{array}{c}-0.51 \\
(0.05)\end{array}$ & $\begin{array}{c}-0.77 \\
(0.04)\end{array}$ & $\begin{array}{l}-0.51 \\
(0.16)\end{array}$ \\
\hline & Jump & $\begin{array}{l}-1.12 \\
(0.25)\end{array}$ & $\begin{array}{l}-1.36 \\
(0.07)\end{array}$ & $\begin{array}{l}-1.21 \\
(0.30)\end{array}$ \\
\hline \multirow{3}{*}{$\begin{array}{l}\text { Vertical } \\
\text { velocity }\end{array}$} & Hop & $\begin{array}{c}2.29 \\
(0.17)\end{array}$ & $\begin{array}{c}2.21 \\
(0.02)\end{array}$ & $\begin{array}{c}2.49 \\
(0.17)\end{array}$ \\
\hline & Step & $\begin{array}{c}1.73 \\
(0.06)\end{array}$ & $\begin{array}{l}1.57 \\
(0.16)\end{array}$ & $\begin{array}{c}1.64 \\
(0.14)\end{array}$ \\
\hline & Jump & $\begin{array}{c}2.66 \\
(0.15)\end{array}$ & $\begin{array}{c}2.32 \\
(0.10)\end{array}$ & $\begin{array}{c}2.50 \\
(0.09)\end{array}$ \\
\hline
\end{tabular}

( ) = Standard deviation; LS = Last stride

작을수록 수직속도 또한 $2.21 \mathrm{~m} / \mathrm{s}$ 로 작게 나타났다. 하지만 스텝과 점프에서 수평속도 손실이 $-0.77 \mathrm{~m} / \mathrm{s},-1.36 \mathrm{~m} / \mathrm{s}$ 로 크게 나타났음에도 불구하고 수직속도가 높게 나타나지 않았 다. 홉, 스텝, 점프 이륙시 수직속도는 모든 선수가 스텝보다 홉과 점프에서 이륙시 수직속도가 높게 나타났고, Olha 선수 는 점프에서 수평속도가 $6.28 \mathrm{~m} / \mathrm{s}$ 로 가장 낮았지만, 수직속 도가 $2.66 \mathrm{~m} / \mathrm{s}$ 로 가장 크게 상승하는 패턴이 나타났다. 그리 고 Olga 선수는 각 국면에서의 이륙시 수직속도가 $2.21 \mathrm{~m} / \mathrm{s}$, $1.57 \mathrm{~m} / \mathrm{s}, 2.32 \mathrm{~m} / \mathrm{s}$ 로 세 선수 중 가장 낮게 나타났다. 


\section{2. 국면별 duty factor와 support factor}

Table 5. Kinematic variables of related to duty factor for hop, step and jump phases

\begin{tabular}{ccccc}
\hline \hline & & Olha & Olga & Caterine \\
\hline & Hop & 0.12 & 0.11 & 0.12 \\
& & $(0.01)$ & $(0.01)$ & $(0.01)$ \\
$\begin{array}{c}\text { Support } \\
\text { time } \\
\text { (sec) }\end{array}$ & Step & 0.16 & 0.15 & 0.13 \\
& & $(0.01)$ & $(0.02)$ & $(0.02)$ \\
& Jump & 0.15 & 0.15 & 0.14 \\
& $(0.01)$ & $(0.01)$ & $(0.01)$ \\
\hline $\begin{array}{c}\text { Phase } \\
\text { period } \\
\text { (sec) }\end{array}$ & Step & 0.55 & 0.53 & 0.69 \\
& & $(0.02)$ & $(0.03)$ & $(0.02)$ \\
& Jump & 0.86 & 0.82 & 0.82 \\
& $(0.02)$ & $(0.00)$ & $(0.04)$ \\
\hline \multirow{2}{*}{$\begin{array}{ccc}\text { Duty } \\
\text { factor }\end{array}$} & Step & 0.29 & 0.017 & 0.17 \\
& Jump & 0.17 & 0.28 & 0.25 \\
\hline \hline
\end{tabular}

( ) = Standard deviation

홉, 스텝, 점프 국면의 duty factor와 관련된 운동학적 변인들은 〈Table 5〉와 같다. Duty factor는 각 국면 수행 에서의 소요시간(phase period)이 길고 지지 시간이 짧을 수록 작게 나타났다. Olha 선수는 홉과 점프에서 duty factor가 0.17로 국면 수행 소요시간 대비 지면에서 발구름 발이 발구름 동작을 수행하는 시간에 대해 동일하게 나타났 다. 반면에 Olga 선수는 홉에서의 duty factor가 0.17로 나타났지만, 점프에서는 0.25 로 국면 수행 소요시간 대비 지면에서 발구름 발이 발구름 동작을 수행하는 시간에 대해 Olha와 Caterine 선수보다 크게 나타났다. Caterine 선수 도 홉과 점프에서 duty factor가 각각 $0.17,0.18$ 로 거의 동일하게 나타났다. 스텝에서는 세 선수 모두 duty factor 값이 0.25 이상으로 스텝 국면 수행 소요시간 대비 지면에 서 발구름 발이 발구름 동작을 수행하는 시간에 대해 홉과 점프에 비해 크게 나타났다.
Table 6. Kinematic variables of related to support factor for hop, step and jump phases

(Unit : sec)

\begin{tabular}{|c|c|c|c|c|c|}
\hline & & & Olha & Olga & Caterine \\
\hline \multirow{3}{*}{\multicolumn{2}{|c|}{$\begin{array}{c}\text { Braking } \\
\text { time }\end{array}$}} & Hop & $\begin{array}{c}0.04 \\
(0.01)\end{array}$ & $\begin{array}{c}0.03 \\
(0.01)\end{array}$ & $\begin{array}{c}0.03 \\
(0.01)\end{array}$ \\
\hline & & Step & $\begin{array}{c}0.05 \\
(0.02)\end{array}$ & $\begin{array}{c}0.04 \\
(0.01)\end{array}$ & $\begin{array}{c}0.02 \\
(0.01)\end{array}$ \\
\hline & & Jump & $\begin{array}{c}0.04 \\
(0.02)\end{array}$ & $\begin{array}{c}0.03 \\
(0.00)\end{array}$ & $\begin{array}{c}0.03 \\
(0.01)\end{array}$ \\
\hline \multirow{3}{*}{\multicolumn{2}{|c|}{$\begin{array}{l}\text { Pushing } \\
\text { time }\end{array}$}} & Hop & $\begin{array}{c}0.08 \\
(0.01)\end{array}$ & $\begin{array}{c}0.08 \\
(0.00)\end{array}$ & $\begin{array}{c}0.09 \\
(0.01)\end{array}$ \\
\hline & & Step & $\begin{array}{c}0.11 \\
(0.01)\end{array}$ & $\begin{array}{c}0.11 \\
(0.01)\end{array}$ & $\begin{array}{c}0.11 \\
(0.02)\end{array}$ \\
\hline & & Jump & $\begin{array}{c}0.11 \\
(0.01)\end{array}$ & $\begin{array}{c}0.12 \\
(0.01)\end{array}$ & $\begin{array}{c}0.11 \\
(0.01)\end{array}$ \\
\hline \multirow{6}{*}{$\begin{array}{l}\text { Support } \\
\text { factor } \\
(\%)\end{array}$} & \multirow{3}{*}{$\begin{array}{l}\text { Braking } \\
\text { time }\end{array}$} & Нор & 33 & 27 & 25 \\
\hline & & Step & 31 & 27 & 15 \\
\hline & & Jump & 27 & 20 & 21 \\
\hline & \multirow{3}{*}{$\begin{array}{l}\text { Pushing } \\
\text { time }\end{array}$} & Hop & 67 & 73 & 75 \\
\hline & & Step & 69 & 73 & 85 \\
\hline & & Jump & 73 & 80 & 79 \\
\hline
\end{tabular}

( ) = Standard deviation

홉, 스텝, 점프 국면의 지지요인(support factor)과 관련 된 운동학적 변인들은 〈Table 6)과 같다. 지지요인의 비율 에서 제동시간은 홉, 스텝, 점프 순으로 점차적으로 비율이 줄어드는 패턴을 보였다. Olha와 Olga 선수에 반하여 Caterine 선수의 경우는 스텝과 점프에서 제동시간 비율이 각각 $15 \%, 21 \%$ 로 상반되는 패턴을 보이는 특징이 있었다. 그리고 Olga 선수는 홉과 스텝에서 $27 \%$ 로 동일한 비율이 나타났다고 점프에서는 $20 \%$ 로 가장 작은 비율을 보였다. 지지요인의 비율에서 추진시간은 홉, 스텝, 점프 순으로 점 차적으로 비율이 증가하는 패턴을 보였다. Olha와 Caterine 선수의 추진시간은 제동시간과 같이 스텝과 점프 에서 상반되는 비율을 보였다. 그리고 Olga 선수는 홉과 스 텝의 추진시간 비율이 $73 \%$ 로 같고 점프에서는 $80 \%$ 로 가장 높게 나타났다. 
160 Jae-Kyun Ryu \& Geon-Tak Kim

Table 7. Pearson's correlation analysis between the kinematic variables of the hop phase

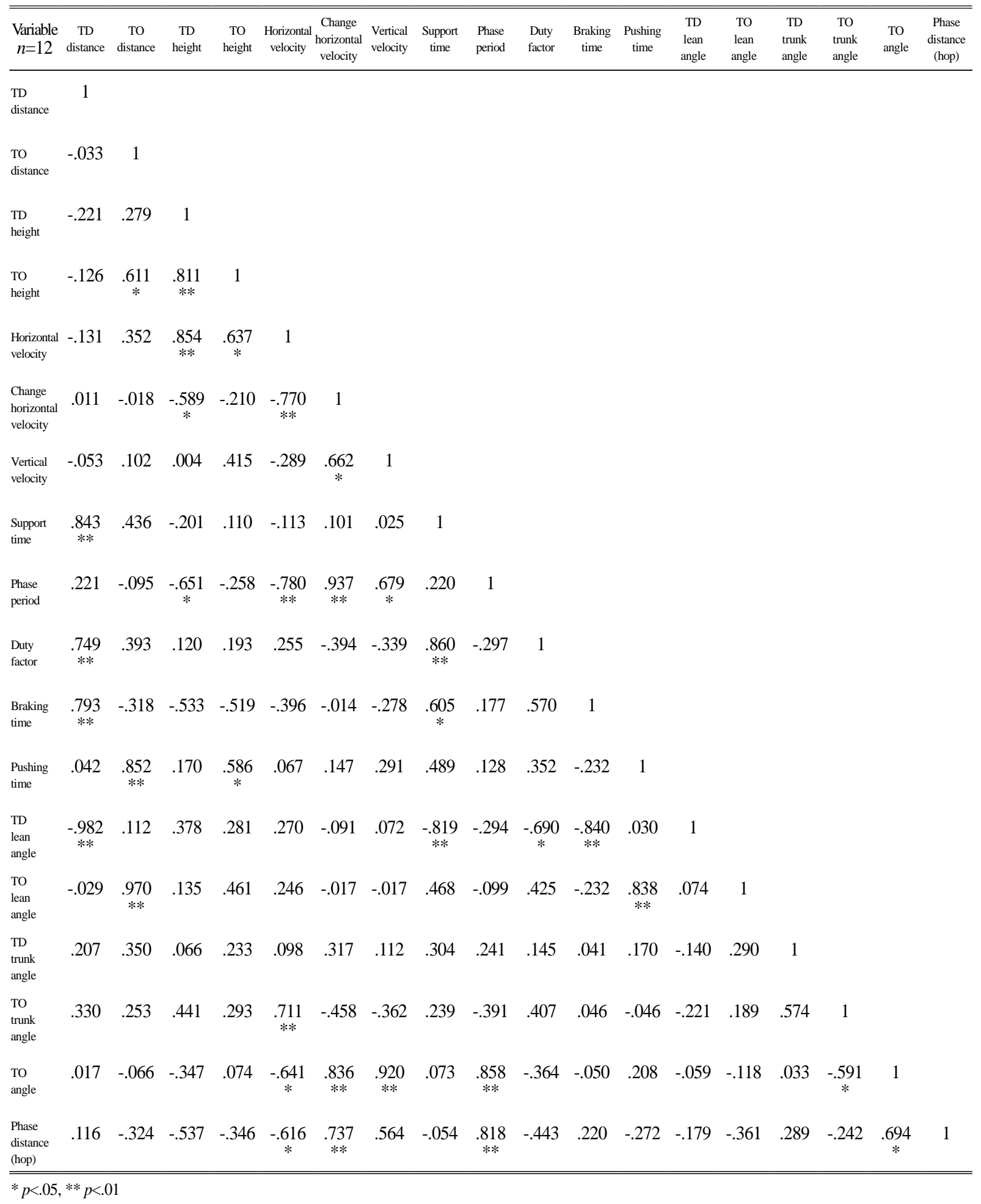


Table 8. Pearson's correlation analysis between the kinematic variables of the step phase

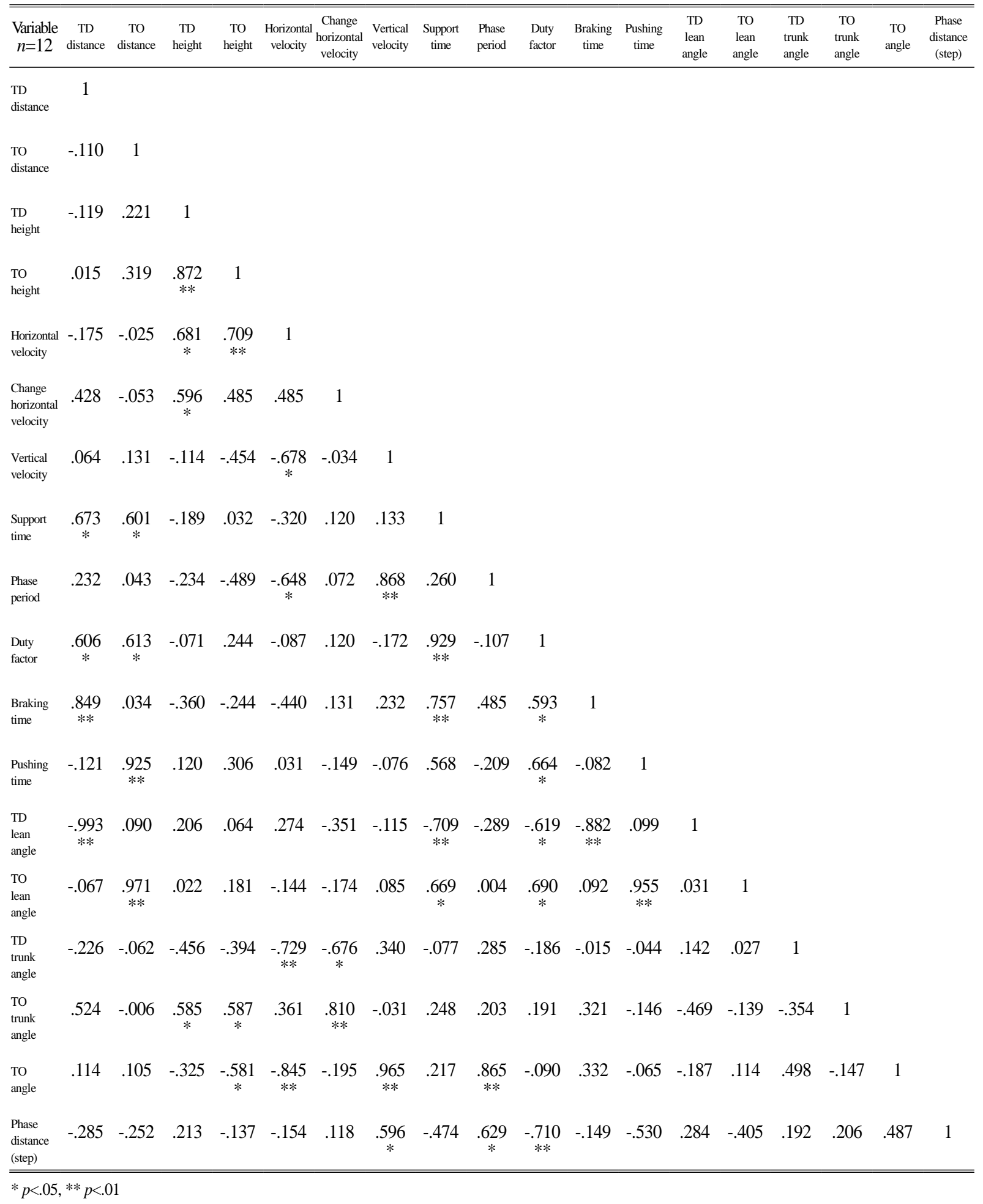


162 Jae-Kyun Ryu \& Geon-Tak Kim

Table 9. Pearson's correlation analysis between the kinematic variables of the jump phase

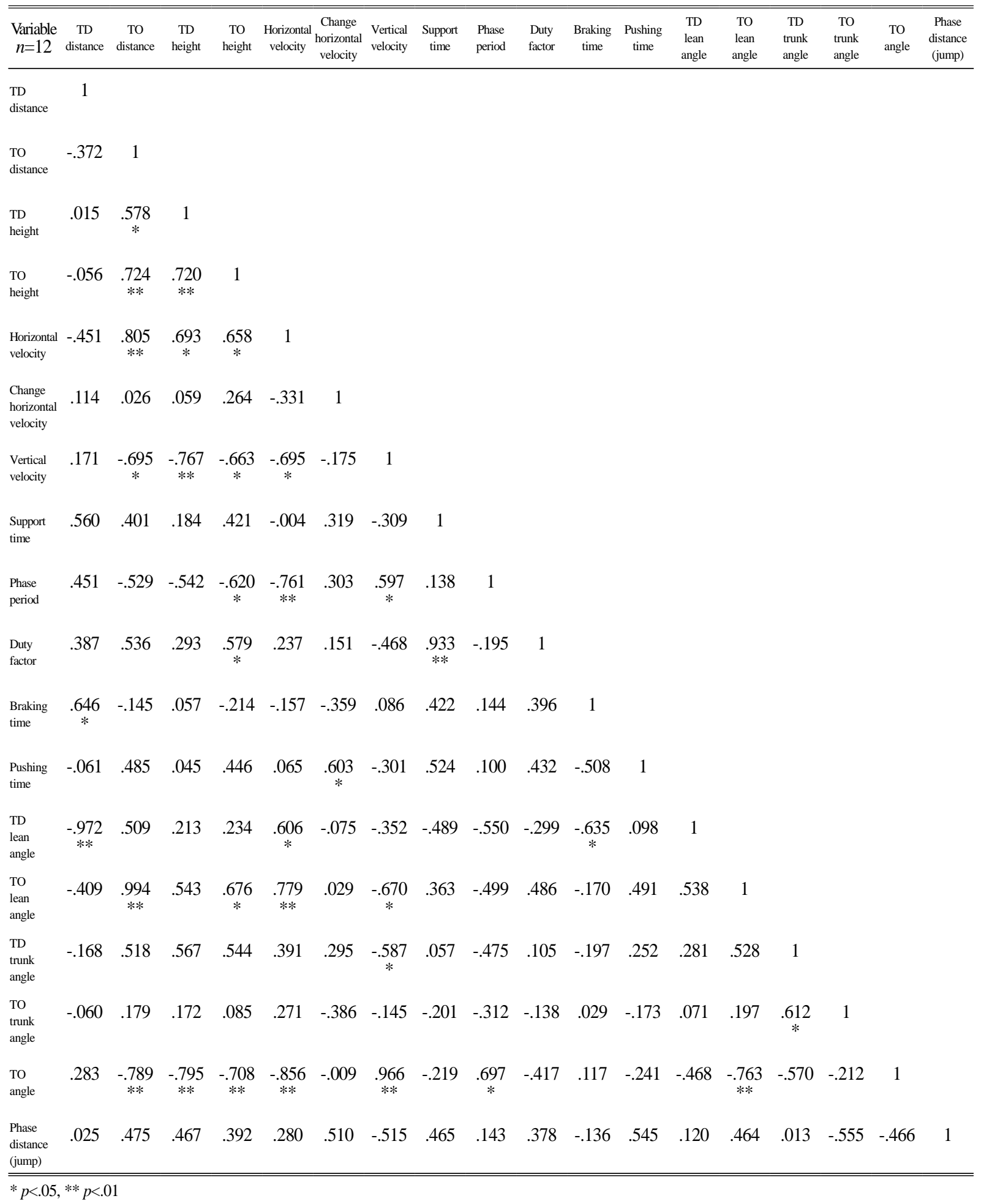




\section{3. 홉, 스텝, 점프 국면별 상관분석 결과}

홉 국면 운동학적 변인들과의 상관분석 결과는 〈Table 7>에 제시하였다. 접지시 수평거리는 지지 시간 $(r=.843$, $p<.01)$ 과는 정적 상관관계, 접지시 신체 기울기 $(r=-.982$, $p$ 〈.01)와는 부적 상관관계가 나타났다. 이륙시 수평거리는 이륙시 신체 무게중심 높이( $r=.611, p<.05)$, 이륙시 신체 기울기 $(r=.970, p<.01)$ 와 정적 상관관계로 나타났다. 접지 시 신체 무게중심 높이는 이륙시 신체 무게중심 높이 $(r=.811, p<.01)$, 수평속도 $(r=.854, p<.01)$ 와 정적 상관관 계, 수평속도 변화율 $(r=-.589, p<.05)$ 과 홉 국면 수행 소요 시간 $(r=-.651, p<.05)$ 와는 부적 상관관계가 나타났다. 수 평속도는 수평속도 변화율( $r=-.770, p<.01)$ 과 홉 국면 수 행 소요시간 $(r=-.780, p<.01)$, 도약 각도 $(r=-.641$, $p<.05)$, 홉 국면 거리( $r=-.616, p<.05)$ 와는 부적 상관관계, 이륙시 상체각도 $(r=.711, p<.01)$ 와 이륙시 신체 무게중심 높이( $r=.637, p<.05)$ 와는 정적 상관관계가 나타났다. 수평 속도 변화율은 수직속도( $r=.662, p<.05)$, 홉 국면 수행 소 요시간 $(r=.937, p<.01)$, 도약 각도 $(r=.836, p<.01)$, 홉 국 면 거리( $r=.737, p<.01)$ 와는 정적 상관관계가 나타났다.

수직속도는 홉 국면 수행 소요시간 $(r=.679, p<.05)$ 과 도 약 각도 $(r=.920, p<.01)$ 와 정적 상관관계가 나타났다. 지지 시간은 duty factor( $r=.860, p$ 〈.01)와 정적 상관관계, 접 지시 신체 기울기 각도 $(r=-.819, p<.01)$ 와는 부적 상관관 계가 나타났다. 홉 국면 수행 소요시간은 도약 각도 $(r=.858$, $p$ 〈.01)와 정적 상관관계가 나타났다.

홉 국면 거리는 수평속도 변화율( $r=.737, p<.01)$, 홉 국 면 수행 소요시간( $r=.818, p<.01)$, 도약 각도( $r=.694$, $p$ 〈.05)와 정적 상관관계가 나타났다. 도약 각도는 이륙시 상체각도 $(r=-.591, p<.05)$ 와 부적 상관관계가 나타났다. Duty factor는 접지시 수평거리( $r=.749, p<.01)$, 지지 시 간 $(r=.860, p<.01)$ 과 정적 상관관계, 접지시 신체 기울기 각도 $(r=-.690, p<.05)$ 와는 부적 상관관계가 나타났다. 제 동시간은 접지시 신체 기울기 각도 $(r=-840, p$ <.01)와 부 적 상관관계, 접지시 수평거리 $(r=.793, p<.01)$, 지지 시간 $(r=.605, p<.05)$ 과는 정적 상관관계가 나타났다. 추진시간 은 이륙시 수평거리( $r=.852, p<.01)$, 이륙시 신체 무게중심 높이( $r=.586, p<.05)$, 이륙시 신체 기울기 각도 $(r=.838$, $p$ 〈.01)와 정적 상관관계가 나타났다.

스텝 국면 운동학적 변인들과의 상관분석 결과는
〈Table 8〉에 제시하였다. 접지시 수평거리는 지지 시간 $(r=.673, p<.05)$, 접지시 신체 기울기 각도 $(r=-.993$, $p$ 〈.01)와 부적 상관관계가 나타났다. 이륙시 수평거리는 지 지 시간 $(r=.601, p<.05)$, 이륙시 신체 기울기 각도 $(r=.971$, $p$ 〈.01)와 정적 상관관계가 나타났다. 접지시 신체 무게중심 높이는 이륙시 신체 무게중심 높이( $r=.872, p<.01)$, 수평속 도( $r=.681, p<.05)$, 수평속도 변화율( $r=.596, p<.05)$, 이 륙시 상체각도 $(r=.585, p<.05)$ 와 정적 상관관계가 나타났 다. 이륙시 신체 무게중심 높이는 수평속도 $(r=.709$, $p<.01)$, 이륙시 상체각도 $(r=.587, p<.05)$ 와 정적 상관관 계, 도약 각도 $(r=-.581, p$ 〈.05)와는 부적 상관관계가 나타 났다. 수평속도는 수직속도 $(r=-.678, p<.05)$, 스텝 국면 수 행 소요시간 $(r=-.648, p<.05)$, 접지시 상체각도 $(r=-.729$, $p<.01)$, 도약 각도 $(r=-.845, p<.01)$ 와 부적 상관관계가 나 타났다. 수평속도 변화율은 접지시 상체각도 $(r=-.676$, $p$ 〈.05)와 부적 상관관계, 이륙시 상체각도( $r=.810, p<.01)$ 와는 정적 상관관계가 나타났다.

수직속도는 스텝 국면 수행 소요시간 $(r=.868, p<.01)$, 도약 각도( $r=.965, p<.01)$, 스텝 국면 거리( $r=.596, p<.05)$ 와 정적 상관관계가 나타났다. 지지 시간은 제동시간 $(r=.757, p<.01)$, 이륙시 신체 기울기 각도( $r=.669, p<.05)$ 와 정적 상관관계, 접지시 신체 기울기 각도 $(r=-.709$, $p$ <.01)와는 부적 상관관계가 나타났다. 스텝 국면 수행 소 요시간은 도약 각도( $r=.865, p<.01)$, 스텝 국면 거리 $(r=.629, p<.05)$ 와 정적 상관관계가 나타났다. Duty factor는 이륙시 신체 기울기 각도 $(r=.690, p<.05)$, 접지시 수평거리 $(r=.606, \quad p$ 〈.05), 이륙시 수평거리 $(r=.613$, $p<.05)$, 지지 시간 $(r=.929, p<.01)$ 과 정적 상관관계, 접지 시 신체 기울기 각도 $(r=-.619, p$ 〈.05)와 스텝 국면 거리 $(r=-.710, p<.01)$ 와는 부적 상관관계가 나타났다.

제동시간은 접지시 수평거리( $r=.849, p<.01)$, duty factor( $r=.593, p<.05)$ 와 정적 상관관계, 접지시 기울기 각 도 $(r=-.882, p<.01)$ 와는 부적 상관관계가 나타났다. 추진 시간은 이륙시 수평거리( $r=.925, p<.01)$, 이륙시 신체 기울 기 각도( $r=.955, p<.01)$, duty factor( $r=.664, p<.05)$ 와 정적 상관관계가 나타났다.

점프 국면 운동학적 변인들과의 상관분석 결과는 〈Table 9>에 제시하였다. 접지시 수평거리는 접지시 신체 기울기 $(r=-.972, p<.01)$ 와 부적 상관관계가 나타났다. 이 륙시 수평거리는 접지시 신체 무게중심 높이( $r=.724$, 
$p$ 〈.01), 수평속도( $r=.805, p<.01)$, 이륙시 신체 기울기 각 도( $r=.994, p<.01)$ 와 정적 상관관계, 수직속도 $(r=-.695$, $p$ 〈.05)와는 부적 상관관계가 나타났다. 접지시 신체 무게중 심 높이는 이륙시 신체 무게중심 높이 $(r=.720, p<.01)$, 수 평속도 $(r=.693, p$ <.05)와 정적 상관관계, 수직속도 $(r=-.767, p<.01)$ 와는 부적 상관관계가 나타났다. 이륙시 신체 무게중심 높이는 수평속도( $r=.658, p<.05)$, duty factor( $r=.579, p<.05)$, 이륙시 신체 기울기 각도( $r=.676$, $p<.05)$ 와 정적 상관관계, 수직속도 $(r=-.663, p<.05)$, 점프 국면 수행 소요시간 $(r=-.620, p$ <.05)과는 부적 상관관계가 나타났다. 수평속도는 수직속도( $r=-.695, p$ 〈.05), 점프 국 면 수행 소요시간 $(r=-.761, p<.01)$ 와 부적 상관관계, 접지 시 신체 기울기 각도( $r=.606, p<.05)$, 이륙시 신체 기울기 각도 $(r=.779, p$ 〈.01)와는 정적 상관관계가 나타났다.

수직속도는 점프 국면 수행 소요시간 $(r=.597, p<.05)$ 와 정적 상관관계, 이륙시 신체 기울기 각도( $r=-.670, p<.05)$, 접지시 상체각도 $(r=-.587, p$ 〈.05)와 부적 상관관계가 나타 났다. 접지시 상체각도는 이륙시 상체각도( $r=.612, p<.05)$ 와 정적 상관관계가 나타났다. 도약 각도는 수직속도 ( $r=.966, p<.01)$, 점프 국면 수행 소요시간 $(r=.697, p<.05)$ 와 정적 상관관계, 이륙시 수평거리 $(r=-.789, p<.01)$, 접지 시 신체 무게중심 높이( $r=-.795, p<.01)$, 이륙시 신체 무게 중심 높이 $(r=-.708, p<.01)$, 수평속도 $(r=-.856, p<.01)$, 이륙시 신체 기울기 각도( $r=-.763, p<.01)$ 와는 부적 상관 관계가 나타났다.

제동시간은 접지시 수평거리 $(r=.646, p<.05)$ 와 정적 상 관관계 접지시 신체 기울기 각도( $r=-.635, p$ 〈.05)와는 부 적 상관관계가 나타났다. 추진시간은 수평속도 변화율 $(r=.603, p<.05)$ 과 정적 상관관계가 나타났다.

\section{4. 제동시간과 추진시간에 관련된 운동학적 변인}

제동시간과 추진시간에 통계적으로 유의한 상관관계가 나타나는 운동학적 변인들을 선별하였고, 선별된 변인과 인 과관계가 있는 변인도 함께 제시하였다.

제동시간과 관련된 운동학적 변인과 수평·수직속도와 관 계가 있는 도약 각도와 상체각도의 결과는 〈Table 10〉과 같다. 홉에서는 제동시간이 접지시 신체 기울기 각도 $(r=-.840, p<.01)$ 와 접지시 수평거리 $(r=.793, p<.01)$ 와 상 관관계가 통계적으로 유의하게 나타났다. 스텝에서는 제동 시간이 접지시 수평거리( $r=.849, p$ <.01)와 접지시 신체 기 울기 각도 $(r=-.882, p$ 〈.01)와 상관관계가 통계적으로 유의 하게 나타났다. 점프에서는 제동시간이 접지시 수평거리 $(r=.646, p<.05)$, 접지시 신체 기울기 각도( $r=-.635$, $p$ <.05)와 상관관계가 통계적으로 유의하게 나타났다 (Table 7, 8, 9). 따라서 세 국면에서 접지시 수평거리의 일 관성은 Olha와 Olga 선수가 다소 일정하게 나타났으며 특 히 Olga 선수는 $0.43 \mathrm{~m}, 0.42 \mathrm{~m}, 0.42 \mathrm{~m}$ 로 가장 일정한 패턴을 보였다. 국면별 접지시 신체 무게중심 높이는 세 선 수 모두 "low-high-medium" 패턴으로 나타났다. 그리고 접지시 신체 기울기 각 또한 Olha와 Olga 선수가 세 국면 에서 각각 $-27^{\circ},-23^{\circ},-26^{\circ}$ 와 $-23^{\circ},-22^{\circ},-23^{\circ}$ 로 거의 일 정한 평균 후경 기울기 각이 나타났다. 국면별 접지시 상체 각도는 Olha와 Olga 선수가 국면별로 전경과 후경 자세가 혼용되어 일관성은 찾아볼 수 없었으며, 유일하게 Caterine 선수만이 전경 자세를 하는 것으로 나타났다. 국

Table 10. Distance, height and angle variables of related to braking time for hop, step and jump phases

\begin{tabular}{|c|c|c|c|c|c|c|c|c|c|c|c|c|c|c|c|}
\hline & \multicolumn{3}{|c|}{$\begin{array}{l}\text { Touch-down } \\
\text { distance } \\
(\mathrm{m})\end{array}$} & \multicolumn{3}{|c|}{$\begin{array}{l}\text { Touch-down } \\
\text { height } \\
(\%)\end{array}$} & \multicolumn{3}{|c|}{$\begin{array}{l}\text { Touch-down } \\
\text { lean angle } \\
\text { (deg.) }\end{array}$} & \multicolumn{3}{|c|}{$\begin{array}{l}\text { Touch-down } \\
\text { trunk angle } \\
\text { (deg.) }\end{array}$} & \multicolumn{3}{|c|}{$\begin{array}{l}\text { Take-off } \\
\text { angle } \\
\text { (deg.) }\end{array}$} \\
\hline & Нор & Step & Jump & Нор & Step & Jump & Hop & Step & Jump & Hop & Step & Jump & Hop & Step & Jump \\
\hline Olha & $\begin{array}{c}0.47 \\
(0.10)\end{array}$ & $\begin{array}{c}0.41 \\
(0.10)\end{array}$ & $\begin{array}{c}0.45 \\
(0.06)\end{array}$ & 58 & 63 & 60 & $\begin{array}{c}-27 \\
(5.25)\end{array}$ & $\begin{array}{c}-23 \\
(5.46)\end{array}$ & $\begin{array}{c}-26 \\
(3.75)\end{array}$ & $\begin{array}{c}-1 \\
(1.66)\end{array}$ & $\begin{array}{c}4 \\
(1.25)\end{array}$ & $\begin{array}{c}-4 \\
(4.26)\end{array}$ & $\begin{array}{c}16 \\
(1.25)\end{array}$ & $\begin{array}{c}13 \\
(0.64)\end{array}$ & $\begin{array}{c}23 \\
(1.65)\end{array}$ \\
\hline Olga & $\begin{array}{c}0.43 \\
(0.07)\end{array}$ & $\begin{array}{c}0.42 \\
(0.08)\end{array}$ & $\begin{array}{c}0.42 \\
(0.06)\end{array}$ & 60 & 62 & 61 & $\begin{array}{c}-23 \\
(4.24)\end{array}$ & $\begin{array}{c}-22 \\
(4.13)\end{array}$ & $\begin{array}{c}-23 \\
(3.51)\end{array}$ & $\begin{array}{c}0 \\
(2.35)\end{array}$ & $\begin{array}{c}-6 \\
(2.48)\end{array}$ & $\begin{array}{c}2 \\
(1.78)\end{array}$ & $\begin{array}{c}14 \\
(0.03)\end{array}$ & $\begin{array}{c}11 \\
(1.22)\end{array}$ & $\begin{array}{c}19 \\
(0.60)\end{array}$ \\
\hline Caterine & $\begin{array}{c}0.43 \\
(0.06)\end{array}$ & $\begin{array}{c}0.27 \\
(0.09)\end{array}$ & $\begin{array}{c}0.43 \\
(0.06)\end{array}$ & 59 & 62 & 61 & $\begin{array}{c}-24 \\
(3.25)\end{array}$ & $\begin{array}{c}-15 \\
(4.74)\end{array}$ & $\begin{array}{c}-24 \\
(3.30)\end{array}$ & $\begin{array}{c}3 \\
(3.19)\end{array}$ & $\begin{array}{c}4 \\
(1.85)\end{array}$ & $\begin{array}{c}6 \\
(3.42)\end{array}$ & $\begin{array}{c}17 \\
(1.29)\end{array}$ & $\begin{array}{c}12 \\
(1.13)\end{array}$ & $\begin{array}{c}21 \\
(0.98)\end{array}$ \\
\hline
\end{tabular}

( ) = Standard deviation; (+) = Forward; (-) = Backward 
Table 11. Distance, height and angle variables of related to pushing time for hop, step and jump phases

\begin{tabular}{|c|c|c|c|c|c|c|c|c|c|c|c|c|}
\hline & \multicolumn{3}{|c|}{$\begin{array}{c}\text { Take-off } \\
\text { distance } \\
\text { (m) }\end{array}$} & \multicolumn{3}{|c|}{$\begin{array}{c}\text { Take-off } \\
\text { height } \\
(\%)\end{array}$} & \multicolumn{3}{|c|}{$\begin{array}{c}\text { Take-off } \\
\text { lean angle } \\
\text { (deg.) }\end{array}$} & \multicolumn{3}{|c|}{$\begin{array}{l}\text { Take-off } \\
\text { trunk angle } \\
\text { (deg.) }\end{array}$} \\
\hline & Нор & Step & Jump & Нор & Step & Jump & Нор & Step & Jump & Hop & Step & Jump \\
\hline Olha & $\begin{array}{c}0.45 \\
(0.03)\end{array}$ & $\begin{array}{c}0.67 \\
(0.03)\end{array}$ & $\begin{array}{c}0.42 \\
(0.04)\end{array}$ & 65 & 64 & 68 & $\begin{array}{c}24 \\
(1.09)\end{array}$ & $\begin{array}{c}35 \\
(1.61)\end{array}$ & $\begin{array}{c}21 \\
(1.80)\end{array}$ & $\begin{array}{c}3 \\
(4.32)\end{array}$ & $\begin{array}{c}10 \\
(1.31)\end{array}$ & $\begin{array}{c}7 \\
(6.29)\end{array}$ \\
\hline Olga & $\begin{array}{c}0.49 \\
(0.03)\end{array}$ & $\begin{array}{c}0.67 \\
(0.07)\end{array}$ & $\begin{array}{c}0.55 \\
(0.06)\end{array}$ & 67 & 65 & 71 & $\begin{array}{c}25 \\
(1.62)\end{array}$ & $\begin{array}{c}33 \\
(3.27)\end{array}$ & $\begin{array}{c}26 \\
(2.55)\end{array}$ & $\begin{array}{c}9 \\
(4.54)\end{array}$ & $\begin{array}{c}15 \\
(2.55)\end{array}$ & $\begin{array}{c}10 \\
(5.50)\end{array}$ \\
\hline Caterine & $\begin{array}{c}0.52 \\
(0.06)\end{array}$ & $\begin{array}{c}0.64 \\
(0.11)\end{array}$ & $\begin{array}{c}0.50 \\
(0.06)\end{array}$ & 68 & 66 & 70 & $\begin{array}{c}26 \\
(2.88)\end{array}$ & $\begin{array}{c}33 \\
(4.33)\end{array}$ & $\begin{array}{c}24 \\
(2.40)\end{array}$ & $\begin{array}{c}5 \\
(3.57)\end{array}$ & $\begin{array}{c}1 \\
(1.21)\end{array}$ & $\begin{array}{c}14 \\
(5.38)\end{array}$ \\
\hline
\end{tabular}

( ) = Standard deviation; $(+)$ = Forward; $(-)$ = Backward

면별 도약 각도는 Olha 선수의 경우 점프에서 접지시 수평 거리가 $0.45 \mathrm{~m}$ 로 가장 길었고 도약 각도는 $23^{\circ}$ 로 가장 높 게 나타났다. 반면에 Olga 선수는 점프에서 접지시 수평거 리가 $0.42 \mathrm{~m}$ 로 가장 짧았고 홉, 스텝, 점프의 도약 각도는 다른 선수들에 비해 낮게 나타났다.

추진시간과 관련된 운동학적 변인의 결과는 〈Table 11〉 과 같다. 홉에서 추진시간은 이륙시 수평거리 $(r=.852$, $p<.01)$, 이륙시 신체 무게중심 높이( $r=.586, p<.05)$, 이륙 시 신체 기울기 각도 $(r=.838, p$ 〈.01)와 통계적으로 유의한 상관관계가 나타났다. 스텝에서 추진시간은 이륙시 수평거 리(r=.925, $p<.01)$, 이륙시 신체 기울기 각도( $r=.955$, $p$ 〈.01)과 통계적으로 유의한 상관관계가 나타났다. 점프에 서 추진시간은 수평속도 변화율( $r=.603, p$ <.05)과 통계적 으로 유의한 상관관계가 나타났다(Table 7, 8, 9). 스텝 국 면에서의 이륙시 수평거리는 Olha, Olga, Caterine 세 선 수 모두 각각 $0.67 \mathrm{~m}, 0.67 \mathrm{~m}, 0.64 \mathrm{~m}$ 로 홉, 점프 국면보 다 길게 나타났다. 국면별 이륙시 신체 무게중심 높이는 "medium-low-high" 패턴으로 나타났다. 이륙시 신체 기 울기 각도는 스텝에서 세 선수 모두 $33^{\circ}$ 이상으로 나타났고, 점프에서는 Olga 선수가 $26^{\circ}$ 로 가장 크게 나타났다. 그리 고 이륙시 상체각도는 Olha와 Olga 선수가 스텝에서 각각 $10^{\circ}$ 와 $15^{\circ}$, Caterine 선수는 점프에서 $14^{\circ}$ 로 큰 전경 자세 가 나타났고, 세 선수 모두 다양한 패턴이 나타났다.

\section{논의}

본 연구는 세계 엘리트 여자 세단뛰기선수들의 유효시기 별 동작에 대한 운동학적 변인들의 차이와 일관성을 조사하 여 경기력 수준을 평가하기 위해 수행되었다.

아무리 경기력이 뛰어난 선수일지라도 구름판 한계선을 넘게 되면 공식기록으로 인정받지 못하기 때문에 도움닫기 를 통한 구름판에서의 발구름 정확성과 홉, 스텝, 점프의 운 동수행 능력에 따른 거리 조절 능력이 필수적이다. 즉, 선수 들은 거리 손실을 최소화하여 좋은 기록을 세우기 위해 발이 구름판을 정확하게 밟는 것이 중요하다.

도움닫기 마지막 세 스트라이드(페널티메이트 구간 스트 라이드) 수행패턴은 세 선수가 각각 다르게 나타났으며, 특 히 마지막 스트라이드 거리(1SL)의 편차가 크게 나타났다는 것은 도움닫기 발구름 동작의 일관성이 떨어지는 것으로 홉 이륙시 수평 및 수직속도의 가변성이 크다는 것을 의미한 다. 이와 동시에 시기의 성공과 실패율을 결정하는 원인이 며 시기의 성공에 대한 경기력 평가 기준이 된다고 할 수 있 다. 성공 시기율이 높을수록 발구름 손실 거리가 작은 것으 로 나타났으며, 총 6번의 시기 중 성공률이 50\%인 Olga 선 수가 결과적으로 발구름 위치의 일관성이 떨어진다고 볼 수 있다.

도움닫기의 마지막 스트라이드에서 수평속도가 높을수 록 경기력 향상과 관련이 있다는 것은 선행연구들에서 이미 밝혀진 결과이지만, 이러한 수평속도가 홉 이륙 순간으로 연결되지 못하면 오히려 경기력을 저해하는 원인이 된다 
(Yu \& Hay, 1995, 1996; Yu, 1999; Ryu, 2005; Song \& Ryu, 2010; Liu \& Yu, 2012). 본 연구에서 Caterine 선수 의 경우는 마지막 스트라이드 수평속도가 $9.70 \mathrm{~m} / \mathrm{s}$ 에서 홉 이륙 순간에 $8.28 \mathrm{~m} / \mathrm{s}$ 로 나타나 약 $-1.42 \mathrm{~m} / \mathrm{s}$ 감소하였으 며 이러한 손실된 결과가 앞서 말한 원인의 주장을 뒷받침한 다. Olga 선수는 다른 선수들보다 마지막 스트라이드(LS)의 수평·수직속도의 편차가 각각 $\pm 0.09 \mathrm{~m} / \mathrm{s}, \pm 0.02 \mathrm{~m} / \mathrm{s}$ 로 가장 작게 나타났고, 구름판에서 거리 손실은 평균 $-0.29 \mathrm{~m}$ 로 가장 길게 나타났다. 이러한 현상은 비교적 일관된 속도 를 유지하여 과감하게 홉 동작을 수행하는 것으로 볼 수 있 으나 밸런스형 기술을 사용하는 선수의 마지막 세 스트라이 드 보폭 변화가 “길게-짧게-보통”의 스트라이드 동작이 이 루어지기 때문에 마지막 두 번째 스트라이드를 짧게 하는 달 리기 동작과 마지막에서의 스트라이드 보폭 거리를 길게 하 는 동작으로 인해 발구름 거리 조절 능력이 떨어진다고 할 수 있다. Olga 선수는 마지막 스트라이드에서의 보폭을 발 구름 위치에 맞춰 작게 조절하지 않기 때문에 홉에서 수평속 도 손실이 $-0.37 \mathrm{~m} / \mathrm{s}$ 로 상대적으로 낮게 나타났으며, 홉 이 륙 순간의 수평속도가 $8.81 \mathrm{~m} / \mathrm{s}$ 로 가장 높은 결과로 이어 진 것으로 사료된다. 따라서 경기력 향상을 위해 도움닫기 수평속도를 홉, 스텝, 점프를 위해 조절 가능한 속도로 도움 닫기를 수행하여야 하며 각 국면의 수평속도 변화율이 낮아 야 한다고 할 수 있다. 따라서 이러한 내용이 선수들의 경기 력 수준을 판단하는 운동학적 요소라 할 수 있다.

Duty factor가 홉, 스텝, 점프에서 일정하게 나타나면 각 국면 발구름 발의 수행 동작이 일정하다는 것이며 이는 발구름 동작을 정확하게 수행한다는 것이다. 따라서 경기력 수준과 기술 유형을 분류하는 동시에 할 수 있는 근거자료로 활용할 수 있다고 판단된다. Olha와 Caterine 선수는 홉과 점프에서 duty factor가 동일하게 나타났고, 반면에 Olga 선수는 홉에서 duty factor가 0.17 로 나타났지만, 점프에 서 0.25 로 크게 나타났다. 스텝에서는 세 선수 모두 0.25 이 상으로 홉과 점프에 비해 크게 나타났다. 이러한 결과는 3 가 지 기술 유형의 국면비 특성과 관련이 있으며 밸런스 기술 유형은 Olga 선수처럼 스텝과 점프의 duty factor 값이 0.25 이상을 보이면 밸런스 기술 유형이라 할 수 있다. 그리 고 홉과 점프에서 duty factor 값이 0.17 에 있는 경우 홉 강 조형 기술을 수행한다고 판단할 수 있으며, 점프 강조형 기 술인 경우 홉, 스텝, 점프의 duty factor 값이 거의 차이를 보이지 않을 것으로 판단된다. 지지요인(support factor)은 각 국면의 지지 시간을 제 동시간과 추진시간 국면으로 분할 하여 백분율로 산출된 변 인으로 홉 강조 기술 유형인 Olha, Caterine 선수의 경우, 스텝과 점프에서 제동시간 비율이 상반되는 패턴을 보이는 특징이 있었다. 이는 홉의 비중을 높여 홉 거리를 멀리 뛰기 때문에 나타난 현상이며 특히 스텝에서의 연결 상황이 점프 거리에 영향을 미친다고 할 수 있다. 한편, Olga 선수는 밸 런스 기술 유형으로 홉과 스텝의 경우 동일한 비율이 나타났 고, 점프에서는 더 작은 비율을 보였다. 특히 점프에서 낮은 비율이 나타난 이유는 홉의 수평속도 변화율이 가장 낮고 스 텝에서 수평속도를 높게 유지했기 때문이며, 신체가 운동 진행 방향의 관성으로 인해 짧아진 것이다. 이는 짧은 시간 에 수평속도의 손실이 크고 수직속도를 높게 얻을 수 없는 결과를 초래한다. Olha와 Caterine 선수의 추진시간은 제 동시간과 같이 기술 유형에 따라 스텝과 점프가 상반되는 결 과를 보였다. 그리고 밸런스 기술 유형은 홉과 스텝의 추진 시간 비율이 같고 점프에서 높게 나타났다. 따라서 duty factor는 경기력 수준과 기술 유형을 동시에 판단할 수 있 고, support factor는 경기력 수준을 판단하는 변인보다는 기술 유형을 분류하는 근거자료에 더 가까운 변인으로 보는 것이 타당하다고 하겠다.

국면별 접지시 수평거리의 일관성이 높은 Olga 선수는 밸런스 기술 유형을 사용하기 때문에 나타난 것이라고 할 수 있다. 홉, 스텝, 점프 국면별 상관분석 결과, 각 국면을 수행 하는 동안 신체 무게중심의 이동 패턴은 접지와 이륙시 수평 거리와 신체 기울기 및 상체각도에 따라서 변화 패턴이 결정 되고 이후 국면별 소요시간에 영향을 미치게 된다. 홉, 스텝, 점프 국면에서 접지시 수평거리와 제동시간은 통계적으로 유의한 상관관계가 나타났다(홉:( $r=.793, \quad p<.01)$, 스 텝:( $r=.849, p<.01)$, 점프:( $r=.646, p<.05))$. 접지시 수평거 리는 제동시간과 관련이 있는 신체 무게중심의 이동 패턴, 접지와 이륙시 수평거리와 신체 기울기 및 상체각도와 같은 운동학적 변인들과 상호관계에 있기 때문에 경기력 판별 기 준보다는 선호하는 기술 유형에 따라 나타나는 결과로 기술 유형의 판별 기준으로 보는 것이 타당하다.

홉, 스텝, 점프 국면에서 제동 및 추진이 일어나는 시점은 한 발이 지면에 닿고 있는 순간으로 이 국면에서 신체의 동 작이 모두 변화되고 이후 수행되는 동작의 결과에 영향을 미 치게 된다. 그러므로 이 두 변인의 상호관계 변화와 관련된 운동학적 변인들은 경기력에 크게 영향을 미치는 변인이라 
할 수 있다.

Maraj 등(1993)은 주어진 운동 종목에서 기술 과제는 숙 련된 선수일수록 운동기술 수행의 가변성이 작다고 보고하 였다. 이와 같이 홉, 스텝, 점프 국면에서 제동과 추진에 관 련되어 선정된 운동학적 변인들은 서로 영향을 미치고 있다 는 것을 알 수 있다. 이렇게 선정된 변인들이 총 6번의 시기 를 수행하는 동안 일관성 있게 나타난다면 시기별 기록의 차 이가 작을 것으로 판단된다.

Allen 등(2013)은 수평속도 손실과 수직속도 이득의 전 환에서 선형관계가 나타나지 않는 것은 각 국면 접지 순간에 신체의 기울기 각도 차이에서 기인한다고 하였다. 본 연구 에서는 각 국면에서의 제동과 추진과 관련된 운동학적 변인 간 기술 유형에 따라 가변성이 높게 나타나 경기력 수준의 일관성을 판별할 수 있는 근거자료로 활용될 수 있을 것으로 판단된다. 그리고 각각의 시기에서 수행되는 운동기술과 관 련된 운동학적 변인의 일관성은 숙련된 운동수행의 특징으 로서 전체 뛴 거리의 가변성은 그 운동을 수행하는데 소요되 는 상대적 시간 가변성에 의해 결정된다(Maraj et. al., 1993). 따라서 최종적으로 다양한 외부 조건에서도 일정한 변화를 유지할 수 있는 선수가 경기력 수준의 일관성이 높다 고 할 수 있으며 이러한 결과는 경기력에 영향을 미치게 되 고 경기력 수준을 판별할 수 있는 기준이 될 수 있다. 더불어 본 연구에서 선정한 제동과 추진에 관련된 운동학적 변인들 은 기술 유형에 따른 운동학적 특성을 판별하는 근거자료가 될 수 있는 변인들이기도 하다.

\section{결론}

2011년 대구세계육상선수권대회 여자 세단뛰기 결승에 진출하여 입상한 3 명의 선수에 대한 운동학적 분석을 통하 여 변인 간 차이와 일관성을 조사한 결과 다음과 같은 결론 을 얻었다.

1. 마지막 스트라이드 거리(1SL)에서 스트라이드 거리 의 편차가 크다는 것은 일정한 발구름 동작을 위한 달 리기 자세를 수행하지 못한다는 것이다. 따라서 세 선 수는 마지막 스트라이드 수행 동작을 일정하게 수행 하는 능력을 향상시켜야 하며 홉 착지까지 도움닫기 스피드를 연결해야 한다. 그리고 구름판에 발구름 발
의 정확성을 높이기 위해서는 수행하는 기술 유형에 맞추어 일정한 마지막 스트라이드 거리가 유지되어야 만 구름판에서의 손실을 줄이고 도움닫기 발구름 동 작의 일관성이 높아져 시기별 성공률도 높아진다.

2. 도움닫기 수평속도는 홉, 스텝, 점프를 위해 조절 가 능한 속도로 수행되어야 국면별 수평속도 손실을 최 소화할 수 있다. 그리고 각 국면에서의 수평속도 감속 변화폭이 적고 스텝과 점프에서 수직속도가 높을수록 경기력이 우수하다.

3. Duty factor는 경기력 수준과 기술 유형을 동시에 판 단할 수 있으며, support factor는 경기력 수준을 판 단하는 변인이기보다는 홉, 스텝, 점프의 기술 유형을 분류할 수 있는 변인이다.

4. 홉, 스텝, 점프 국면에서 접지시 수평거리는 제동시간 과 관련이 있는 각 국면 신체 무게중심의 이동 패턴, 접지와 이륙시 수평거리, 신체 기울기 각도 그리고 상 체각도와 같은 운동학적 변인들과 함께 보면 경기력 판별 기준보다는 선호하는 기술 유형 판별 기준으로 보아야 한다.

5. 홉, 스텝, 점프에서 제동과 추진과 관련된 운동학적 변인들은 각 유효시기 간에 일관되게 나타나지 않았 기 때문에 동작을 수행하는데 소요되는 상대적 시간 과 국면별 지지 시간(제동과 추진)의 가변성이 일정하 다면 시기별 기록의 차이가 작을 것이다.

\section{참고문헌}

우상연, 서정석, 김호묵, 남기정, 최성범, \& 김용운. (2011). 2011 대구세계육상선수권대회 여자 세단뛰기 경기의 운동학적 분 석. Korean Journal of Sport Biomechanics, 21(5), 621-629.

Abdel-Aziz, Y, I., \& Karara, H. M. (1971). Direct linear transformation from comparator coordinates into object space coordinates into object space coordinates in close-range photogrammetry. In Proceedings of the ASP Symposium on Close=range Photogrammetry, Urbana, University of Illinois, USA (pp. 420-75).

Allen, S. J., King, M. A., \& Yeadon, M. R. (2010). Is a single or double arm technique more advantageous in triple jumping?. Journal of biomechanics, 43(16), 3156-3161. 
Allen, S. J., King, M. A., \& Yeadon, M. R. (2013). Trade-offs between horiaontal and Vertical velocities during triple jumping and the effect on phase distances. Journal of Biomechanics, 46, 979-983.

Fihl, P., \& Moeslund, T. (2010). Recognizing human gait types. Robot Vision, 183-208.

Hay, J. G. (1992). The biomechanics of the triple jump: A review. Journal of Sports Sciences, 10(4), 343-378.

Hay, J. G. (1999). Effort distribution and performance of olympic triple jumpers. Journal of Applied Biomechanics, 15(1), 36-51.

Liu, H., \& Yu, B. (2012). Effects of phase ratio and velocity conversion coefficient on the performance of the triple jump. Journal of Sports Sciences, 30(14), 1529-1536.

Maraj, B. K., Elliott, D., Lee, T. D., \& Pollock, B. J. (1993). Variance and Invariance in Expert and Novice Triple Junipers. Research quarterly for exercise and sport, 64(4), 404-412.

McNeill Alexander, R. (2002). Energetics and optimization of human walking and running: the 2000 Raymond Pearl memorial lecture. American journal of human biology, 14(5), 641-648.

Perttunen, J., Kyrolainen, H., Komi, P. V., \& Heinonen, A. (2000). Biomechanical loading in the triple jump. Journal of sports sciences, 18(5), 363-370.

Ryu, J. K.(2005). A cinematographic analysis of selected kinematic characteristics of intercollegiate man's triple jumpers. The Korea Journal of Physical Education, 44(1), 353-364.

Ryu, J. K., \& Chang, J. K. (2015). The Velocity Conversion Coefficient and Consistency for the Optimal Phase Ratio on the Performance of the Women's Triple Jump. Korean Journal of Sport Biomechanics, 25(1), 39-47.

Song, J. H. \& Ryu, J. K.(2010). The kinematic analysis of the distributional phases and technical styles of the national elite man's triple jumper. Korean Journal of sport Science, 21(2), 1105-1114.

Yu, B., \& Hay, J. G. (1995). Angular momentum and performance in the triple jump: A cross-sectional analysis. Journal of Applied Biomechanics, 11, 81-102.

Yu, B., \& Hay, J. G. (1996). Optimum phase ratio in the triple jump. Journal of Biomechanics, 29, 1283-1289.

Yu, B., \& Andrews, J. G. (1998). The relationship between free limb motions and performance in the triple jump. Journal of Applied Biomechanics, 14(2), 223-237.

$\mathrm{Yu}, \mathrm{B}$. (1999). Horizontal-to-vertical velocity conversion in the triple jump. Journal of Sports Sciences, 17(3), 221-229. 


\title{
세계 여자 세단뛰기선수 공식기록의 운동학적 변인 비교를 통한 경기력 평가
}

\author{
류재균 ${ }^{1}$, 김건탁 ${ }^{2}$ \\ ${ }^{1}$ 경희대학교 교수 \\ ${ }^{2}$ 경희대학교 대학원생
}

[목적] 본 연구의 목적은 경기력 수준을 평가하기 위하여 우수한 세계 엘리트 여자 세단뛰기선수들의 유효 한 시기를 선정하여 선수별 운동학적 변인들의 차이와 일관성을 조사하는 것이다. [방법] 2011년 대구세계육 상선수권대회 여자 세단뛰기에서 입상한 선수 3명을 연구대상으로 선정하였으며, 선수들의 모든 동작을 완전 히 수행한 유효시기만을 분석에 사용하였다. 도움닫기 및 홉, 스텝, 점프 국면의 운동학적 변인들의 평균과 표준편차를 산출하고 각 국면에서의 운동학적 변인들과의 Pearson's 상관분석을 진행하였다. 그리고 제동시간 과 추진시간에 대해 통계적으로 유의한 상관관계가 나타난 운동학적 변인과 이와 연계된 변인들을 구분하여 제시하였다. 또한, 홉, 스텝, 점프 지지 국면에 대한 지지요인(support factor)과 duty factor를 산출하였다. [결과] 총 6번의 시기 중 유효율은 Olha 선수가 $66.7 \%$, Olga 선수가 $50 \%$, Caterine 선수가 $83.3 \%$ 로 나타났 다. 도움닫기 마지막 세 스트라이드 거리는 Olha와 Caterine 선수가 '보통-길게-짧게' 패턴, Olga 선수는 '길 게-짧게-보통' 패턴이 나타났다. Duty factor는 홉 강조형 기술 유형은 홉과 점프에서 duty factor 값의 차이가 없었으나 밸런스형은 점프에서 차이가 있었고, 스텝에서는 두 기술 유형 모두 국면 수행 소요시간 대비 지지 시간이 홉과 점프에 비하여 크게 나타났다. Support factor의 백분율은 Olha와 Caterine 선수의 경우 스텝과 점프에서 제동시간 비율이 상반되는 패턴을 보였다. 반면에, Olga 선수는 홉과 스텝에서 동일한 비율이 나타 났고 점프에서는 더 작은 비율을 보였다. Olha와 Caterine 선수의 추진시간은 제동시간과 같이 스텝과 점프에 서 상반되는 비율을 보였다. 그리고 Olga 선수는 홉과 스텝의 추진시간 비율이 같고 점프에서 높게 나타났다. 세 국면에서 접지 순간 수평거리의 일관성은 Olha와 Olga 선수가 높게 나타났으며 이 중 Olga 선수가 가장 일정한 패턴을 보였다. [결론] 마지막 스트라이드 거리(1SL)가 유지되어야만 구름판에서의 거리 손실을 줄이고 도움닫기 발구름 동작의 일관성이 높아져 시기별 성공률도 높아진다. Duty factor는 경기력 수준과 기술 유형 을 동시에 판단할 수 있고, support factor는 경기력 수준을 판단하는 변인이기보다는 홉, 스텝, 점프의 기술 유형을 분류할 수 있는 변인이다. 세단뛰기 동작을 수행하는데 소요되는 상대적 시간과 국면별 지지 시간(제동 과 추진)의 가변성이 일정하다면 시기별 기록의 차이가 작을 것이다.

주요어: 세계 여자 세단뛰기, 제동, 추진, 일관성, 가변성, 경기력 